\title{
Implementasi Keuangan Publik Islam (Studi Pada Kriterium Kaya Dalam Zakat Terhadap Perda Zakat Di Sulawesi Selatan)
}

\author{
Mustafa Darwis \\ Institut Agama Islam Negeri (IAIN) Bone \\ mustafadarwis90@gmail.com \\ Abdul Rahim \\ Institut Agama Islam Negeri (IAIN) Bone \\ rahimilmi72@gmail.com
}

\begin{abstract}
This study is a study of the criteria that are rich in the zakat profession in Regional Regulations in South Sulawesi. Rich Criterium is a benchmark used by syara 'in establishing zalcat mali's obligation to muzakki. As is the case with professional charities as one part of zakat. The subject is how the criteria are rich in the Zakat Profession, with the sub-subject determining the criteria for rich wealth and wealth of rich zakat as syar'i considerations in the zakat profession in South Sulawesi. This problem is analyzed using the normative theological approach and normative juridical approach, by processing qualitative data, and analyzing data in the form of content analysis. Determination of the criteria for rich in wealth charity (mâl) is a syara decision, only in jurisprudential terms known as 'compulsory zakat requirements', which basically requires zakat only for the rich. There are three indicators that function as criteria for wealth, namely profit from needs and free of debt, productive property, and nișāb. Therefore, the criteria for richness must be one of the syar'i's considerations in determining the profession of zakat which is regulated in the zakat regulation in South Sulawesi. The rich criteria referred to are the ni adalahāb gold union of 20 miśqāl and removed from net income (net), so that the actual zakat issued is an excess of basic needs.
\end{abstract}

Keywords: Rich Criterium, Professional Zakat, Regional Regulation

\begin{abstract}
Abstrak
Studi ini adalah studi tentang kriteria yang kaya dalam profesi zakat dalam Peraturan Daerah di Sulawesi Selatan. Rich Criterium adalah tolak ukur yang digunakan oleh syara 'dalam menetapkan kewajiban zalcat mali kepada muzakki. Seperti halnya dengan amal profesi sebagai salah satu bagian dari zakat māl. Subyeknya adalah

Jurnal Ilmiah Al Tsarwah

Program Magister Program Studi Ekonomi Syariah

Institut Agama Islam Negeri (IAIN) Bone
\end{abstract}


bagaimana kriteria kaya dalam Profesi Zakat, dengan sub-pokok menentukan kriteria kaya kekayaan dan kekayaan zakat kaya sebagai pertimbangan syar'i dalam profesi zakat di Sulawesi Selatan. Masalah ini dianalisis menggunakan pendekatan teologis normatif dan pendekatan yuridis normatif, dengan pengolahan data kualitatif, dan analisis data dalam bentuk analisis isi (content analysis). Penentuan kriteria kaya dalam amal harta (māl) adalah keputusan syara, hanya dalam istilah yurisprudensi yang dikenal sebagai 'persyaratan zakat wajib', yang pada dasarnya mewajibkan zakat hanya untuk orang kaya. Ada tiga indikator yang berfungsi sebagai kriteria kaya, yaitu keuntungan dari kebutuhan dan bebas utang, properti produktif, dan nișāb. Oleh karena itu, kriteria kaya harus menjadi salah satu pertimbangan syar'i dalam menetapkan profesi zakat yang diatur dalam peraturan zakat di Sulawesi Selatan. Kriteria kaya yang dimaksud adalah kesatuan nișāb emas 20 miśqāl dan dihapus dari laba bersih (net), sehingga zakat yang dikeluarkan sebenarnya adalah kelebihan dari kebutuhan dasar.

Kata Kunci: Rich Criterium, Zakat Profesi, Peraturan Daerah

\section{PENDAHULUAN}

Pada zaman Rasulullah saw. berbagai jenis zakat telah diatur secara detail baik nișāb, haul, maupun kadar zakatnya. Di antara zakat yang telah ada pada zaman Rasulullah saw. yaitu, zakat logam mulia (emas dan perak), zakat hasil peternakan (unta, sapi, dan kambing), zakat perniagaan, zakat hasil bumi (pertanian). ${ }^{1}$

Namun seiring perubahan dan perkembangan zaman, dewasa ini usaha-usaha ekonomi di berbagai sektor baik pertanian, perkebunan, peternakan, perdagangan, perindustrian, jasa dan lain sebagainya semakin luas yang semuanya itu mendatangkan keuntungan harta benda. Berkaitan dengan semakin luasnya usaha ekonomi tersebut, perlu adanya penataan dalam pelaksanaan zakat yang pada akhirnya melahirkan apa yang disebut zakat profesi.

Ulama dan ahli hukum Islam kontemporer sependapat, bahwa penghasilan dari pekerjaan tertentu (profesi) merupakan obyek zakat yang baru saat ini. Tidak berlebihan jika zakat profesi dinyatakan sebagai zakat yang fenomenal, dengan adanya perbedaan pendapat ulama dalam menqiyaskan zakat profesi kepada zakat pertanian atau diqiyaskan kepada zakat logam mulia. Sebahagian ulama menqiyaskan zakat profesi kepada zakat pertanian. Menurut pendapat ini, tiap profesional/ pegawai/

${ }^{1}$ Andi Sarjan, Keuangan Islam Publik, Teori, Praktek, dan Pengembangannya di Masa Kini, (Watampone: Lukman al-Hakim Press, 2015), h. 17

Jurnal Ilmiah Al Tsarwah

Program Magister Program Studi Ekonomi Syariah

Institut Agama Islam Negeri (IAIN) Bone 
karyawan yang penghasilannya setara dengan harga $653 \mathrm{Kg}$ beras, maka ia sudah wajib menzakati gajinya dalam bentuk bruto. ${ }^{2}$

Besaran zakat profesi diqiyaskan kepada zakat pertanian. Namun, yang wajib dibayar adalah $2,50 \%$, bukan $10 \%$ atau $5 \%$ sebagaimana zakat pertanian yang semestinya. Hasanuddin mengakui, sebagaimana dikutip dalam Andi Sarjan, bahwa penetapan hukum zakat profesi telah terjadi inkonsistensi di dalamnya, yaitu qiyasnya ke pertanian, namun kadar zakatnya adalah logam mulia atau perdagangan. ${ }^{3}$

Dari segi metodologi istinbat tentu inkonsistensi tersebut tidak dibenarkan. Qiyas harus memiliki 'illat yang valid, sehingga melahirkan hukum yang pasti pula. Akibat buruk yang muncul adalah melanggar beberapa ketentuan dan filosofi hukum zakat itu sendiri. Bahwasannya zakat hanya diperintahkan (diwajibkan) bagi yang kaya, dengan analogi zakat profesi ke zakat pertanian dengan nișāb harga dari $653 \mathrm{Kg}$ beras, dapat dipastikan tidak memenuhi kriteria kaya seiring dengan laju inflasi dari waktu ke waktu. Begitu juga, dengan memotong gaji mereka dalam bentuk bruto (kotor), itu artinya menyalahi filosofi nișāb sebagai syarat wajib zakat, yaitu kelebihan dari pemenuhan kebutuhan pokok. ${ }^{4}$ Menurut Husein al-Syahatah sebagaimana dikutip dalam Andi Sarjan, yang paling baik dianut adalah pendapat sebagian fuqaha yang menqiyaskan zakat profesi itu kepada zakat logam mulia (emas dan perak). ${ }^{5}$ Dengan standar nișāb penghasilan senilai 85 gram emas murni. Adapun kadar zakatnya sebesar $2.50 \%$ dan haul selama satu tahun.

Selain itu, yang membuat zakat profesi semakin fenomenal, yaitu sikap antusias sejumlah pemerintah daerah dalam membuat PERDA untuk memberlakukan zakat profesi bagi karyawannya (Pegawai Negeri Sipil). Dari penelitian yang dilakukan penulis, ada sembilan kabupaten/kota di Provinsi Sulawesi Selatan memiliki PERDA tentang pengelolaan zakat. Untuk lebih jelasnya penulis tuangkan dalam bentuk tabel sebagai berikut.

\begin{tabular}{|c|c|}
\hline No. & Daftar PERDA tentang pengelolaan zakat \\
\hline 1 & PERDA Kabupaten Bulukumba No. 2 Tahun 2003 tentang pengelolaan zakat \\
\hline
\end{tabular}

2Didin Hafidhuddin, Zakat dalam Perekonomian Modern, (Cet. I; Jakarta: Gema Insani Press, 2002), h. 97 - 98

${ }^{3}$ Andi Sarjan, Fikih Zakat dalam Kajian Normatif, Kontekstual, dan Kontemporer, (Cet. I ; Yogyakarta: PRUDENT MEDIA, 2013), h. 92

${ }^{4}$ Andi Sarjan, Fikih Zakat, h. 93

${ }^{5}$ Andi Sarjan, Fikih Zakat, h. 94

Jurnal Ilmiah Al Tsarwah

Program Magister Program Studi Ekonomi Syariah

Institut Agama Islam Negeri (IAIN) Bone 


\begin{tabular}{|l|l|}
\hline 2 & PERDA Kabupaten Maros No. 17 Tahun 2005 tentang pengelolaan zakat \\
\hline 3 & PERDA Kota Makassar No.5 Tahun 2006 tentang pengelolaan zakat \\
\hline 4 & PERDA Kota Palopo No.6 Tahun 2006 tentang pengelolaan zakat \\
\hline 5 & PERDA Kabupaten Luwu Timur. No. 3 Tahun 2007 tentang pengelolaan zakat \\
\hline 6 & PERDA Kota Pare-pare. No. 1 Tahun 2007 tentang pengelolaan zakat \\
\hline 7 & PERDA Kabupaten Bone No.13 Tahun 2009 tentang pengelolaan zakat \\
\hline 8 & $\begin{array}{l}\text { PERDA Kabupaten Kepulauan Selayar. No. 12 Tahun } 2011 \text { tentang } \\
\text { pengelolaan zakat }\end{array}$ \\
\hline 9 & PERDA Kabupaten Wajo No. 22 Tahun 2012 tentang pengelolaan zakat \\
\hline
\end{tabular}

Dari hasil bacaan terhadap PERDA tentang pengelolaan zakat tersebut sebelumnya. Pengaturan zakat profesi pada beberapa PERDA yang ada di Sulawesi Selatan masih berbeda-beda. Di Kabupaten Maros misalnya, Pengaturan tentang zakat profesi diqiyaskan ke zakat logam mulia dengan standar nișāb nilai 91,92 gram emas dengan kadar zakat 2,50\% serta haul selama satu tahun. Hal ini diatur di dalam PERDA No.17 Tahun 2005 BAB VIII Pasal 17 tentang besarnya zakat, infaq, dan sedekah. Meski demikian pada tahun 2011 yang lalu. Bupati Maros mengimbau PNS yang ada di wilayah itu untuk mengeluarkan zakat penghasilan (profesi). Untuk PNS golongan I diminta mengeluarkan zakat dan infaq sebesar Rp 5000 sampai Rp 10.000, golongan II sebesar Rp 10.000 sampai Rp 15.000, golongan III sebesar Rp 15.000 sampai Rp 20.000 dan golongan IV sebesar Rp 20.000. ${ }^{6}$

Berbeda halnya dengan PERDA di Kabupaten Maros, PERDA tentang pengelolaan zakat di Kabupaten Bone pada tahun 2009, justru menqiyaskan zakat profesi kepada zakat pertanian dengan nișāb $653 \mathrm{Kg}$ gabah atau harga yang setara dengan itu, kadar zakat $2,50 \%$ dan dikeluarkan saat menerima penghasilan. Sebagaimana yang dijelaskan sebelumnya terlihat adanya inkonsistensi pada dalil hukumnya.

Namun, tidak sedikit pula PERDA yang sistem perhitungan zakat profesinya baik nișāb, haul, maupun kadar zakatnya tidak dijelaskan secara detail dalam pasal demi pasalnya. Ada beberapa PERDA yang menyerahkan perhitungan teknis zakat kepada BAZDA masing-masing, dan adapula PERDA yang justru mengembalikan kepada ketentuan agama Islam yakni fikih zakat. Itu artinya membuka peluang

2016

${ }^{6}$ sulsel.kemenag.go.id/ Efektivitas Perda Zakat di Kabupaten Maros.htm, diakses 28 November

Jurnal Ilmiah Al Tsarwah

Program Magister Program Studi Ekonomi Syariah

Institut Agama Islam Negeri (IAIN) Bone 
perbedaan persepsi masyarakat terkait kewajiban zakat profesi, karena perbedaan dalil hukum.

Permasalahan yang timbul kemudian akibat dari aturan yang berbeda-beda tersebut, khususnya terhadap PERDA yang mengakomodir semua bentuk profesi, yakni terjadi kamuflase ukuran kaya sebagai syarat wajib zakat. Kekhawatiran yang terjadi adalah bukan orang kaya yang berzakat, sehingga menyalahi beberapa ketentuan dan filosofi zakat itu sendiri. Akibat buruk lain yang muncul adalah ketidak-ikhlasan para muzakki dalam mengeluakan zakat.

Berdasar pada uraian-uraian yang telah dipaparkan, maka permasalahan pokok yang dijadikan obyek bahasan adalah bagaimana kriterium kaya dalam zakat Profesi. Agar pembahasan ini dapat terarah, maka masalah pokok yang telah dirumuskan akan dirinci ke dalam sub-sub masalah yakni; bagaimana penetapan kriterium kaya dalam zakat harta; serta, bagaimana kriterium kaya sebagai pertimbangan syar'i dalam PERDA-PERDA zakat profesi di Sulawesi Selatan.

\section{HASIL DAN PEMBAHASAN}

Ayat-ayat dan hadis Nabi saw. menyebut istilah kaya dan fakir miskin dalam berbagai konteks. Secara psikis, orang kaya dapat dipahami sebagai orang yang sejahtera dan senang kehidupannya karena ditunjang oleh materi yang sangat memadai. Sebaliknya, orang miskin dapat dimaknai sebagai orang yang mengalami kesengsaraan hidup akibat tidak memiliki harta yang memadai. Terlepas dari sudut pandang psikis yang sedikit memberi gambaran tentang siapa yang disebut orang kaya dan miskin, yang tak kalah pentingnya adalah sudut pandang perhitungan jumlah harta yang dimiliki untuk mengategorikan secara terukur, apakah seseorang telah dianggap kaya atau miskin. Ayat maupun hadis yang disebutkan sebelumnya tidak menjelaskan secara rinci berapa jumlah harta yang dimiliki seseorang, sehingga ia disebut kaya. ${ }^{7}$

Kriterium atau tolok ukur kaya dan miskin sangat penting ditelusuri dalam kepustakaan Islam untuk menghindari salah kaprah dalam melakukan kewajibankewajiban agama yang bersifat kebendaan, misalnya zakat, infaq, dan sedekah. Seperti yang telah disebutkan, zakat hanya wajib bagi orang-orang kaya saja. Sebaliknya, yang berhak menerima zakat haruslah orang fakir miskin dan yang lainnya (mustahiq), sesuai

${ }^{7}$ Andi Sarjan, Fikih Zakat, h. 14

Jurnal Ilmiah Al Tsarwah

Program Magister Program Studi Ekonomi Syariah

Institut Agama Islam Negeri (IAIN) Bone 
dengan ketetapan Allah swt. dan Rasulullah saw. Berkaitan dengan hal tersebut, pertanyaan yang relevan diajukan adalah indikator apa yang digunakan oleh syara' dalam menentukan seseorang telah kaya.

\section{a. Indikator kriterium kaya}

Berdasarkan ayat dan hadis yang telah dikemukakan sebelumnya, tidak tampak rincian syara' tentang jenis harta dan jumlah kepemilikan harta sehingga seseorang disebut kaya, hanya ada sejumlah indikasi yang dapat ditangkap kearah itu. Sebelumnya dijelaskan bahwa hanya orang-orang kaya yang diwajibkan berzakat, sehingga dalam syarat wajib tersebut (syarat kaya) termasuk di dalamnya syarat-syarat wajib lainnya, seperti kelebihan harta atas kebutuhan pokok dan terbebas dari utang, harta yang berkembang (produktif), dan mencapai nișāb. Syarat-syarat tersebut menjadi indikator kriterium kaya bagi seseorang sehingga baginya diwajibkan zakat. Penjelasan mengenai indikator-indikator tersebut sebagai berikut.

1) Kelebihan harta atas kebutuhan pokok dan terbebas dari utang

Indikator kriterium kaya yang pertama adalah kelebihan harta atas kebutuhan pokok. Dengan teori al-Hājat al-Așliyah, ulama-ulama mazhab Hanafi memberikan penjelasan mengenai maksud dari kebutuhan pokok itu, yaitu sesuatu kebutuhan untuk kelestarian hidup. Seperti, belanja sehari-hari, rumah kediaman, pakaian yang dipakai untuk melindungi tubuh dari panas dan dingin, peralatan kerja, perabot rumah tangga, kendaraan dan buku-buku ilmu pengetahuan untuk kepentingan keluarga. Demikian juga, utang yang perlu dibayar guna melepaskan diri dari keterikatan. ${ }^{8}$

Oleh karena itu, apabila seseorang memiliki sejumlah harta yang perlu dibelanjakannya untuk memenuhi kebutuhan-kebutuhan yang tersebut sebelumnya dan tidak ada kelebihan, maka ia belum termasuk orang kaya, sehingga ia tidak memiliki kewajiban untuk berzakat. Sama halnya dengan hukum bertayammum menjadi boleh karena air yang ada padanya ia berikan kepada seseorang yang kehausan. ${ }^{9}$

Kebutuhan pokok manusia memang berbeda-beda dan dapat berubah dari waktu ke waktu sesuai situasi dan kondisi pada saat itu. Namun, yang menjadi penekanan adalah kebutuhan-kebutuhan pokok orang yang terkena kewajiban zakat, serta kebutuhan-kebutuhan orang di bawah tanggungannya, seperti istri, anak-anak,

\footnotetext{
${ }^{8}$ Yusuf Qardawiy, Fiqh al-Zakāh, Terj. Salman Harun dkk, h. 150

${ }^{9}$ Yusuf Qardawiy, Fiqh al-Zakāh, Terj. Salman Harun dkk, h. 152

Jurnal Ilmiah Al Tsarwah

Program Magister Program Studi Ekonomi Syariah

Institut Agama Islam Negeri (IAIN) Bone
} 
orang tua, dan anggota keluarga yang hidup di bawah tanggungannya berapa pun jumlahnya, kebutuhan mereka itu menjadi kebutuhannya juga.

Menurut Ibnu Abbas, ketika menafsirkan ayat tersebut sebagaimana yang diungkapkan oleh Ibnu Kaṡir dalam tafsirnya "sesuatu yang lebih" adalah "sesuatu yang lebih dari kebutuhan keluarga". Hal ini juga merupakan pendapat dari Ibnu Umar, Mujahid, 'Ațā, Ikrima, Sa'id bin Jubair, Muhammad bin Ka'ab, Hasan, Qatadah, Kāsim, Sālim, Rabi'ah bin Anas, dan lain-lain. Bahwa al-Afwu dalam ayat tersebut adalah "kelebihan dari kebutuhan". ${ }^{10} \mathrm{Hal}$ itu berarti, Allah swt. mewajibkan zakat dari harta seseorang yang lebih dari kebutuhan. Demikian itu, karena seseorang harus mendahulukan kebutuhan diri dan keluarganya daripada kebutuhan orang lain. Oleh karena itu, syariat tidak menuntut agar ia mengeluarkan sesuatu yang dibutuhkannya.

2) Harta yang berkembang (produktif)

Pada ayat-ayat al-Qur'an dan hadis yang tersebut sebelumnya, tidak diungkapkan secara eksplisit mengenai jenis harta yang menjadikan seseorang disebut kaya, namun ada sebuah indikasi yang perlu dicermati. Kalau diperhatikan firman Allah swt. dan hadis-hadis Nabi saw. diperoleh petunjuk bahwa harta yang produktif saja yang dapat menjadikan seseorang disebut kaya. Dengan harta produktif dapat dijadikan sebagai modal dagang atau investasi, sehingga harta seseorang memungkinkan semakin bertambah jumlahnya.

Ada banyak jenis harta produktif yang diperkenalkan oleh Allah swt. dan RasulNya saw. Misalnya, emas, perak, hewan ternak, hasil-hasil bumi, dan barang dagangan. Harta-harta semacam ini pula yang dinyatakan oleh Allah swt. dan RasulNya saw. berpotensi sebagai sumber zakat. Harta produktif tersebut dikembangkan agar mendatangkan harta kekayaan baru sehingga tidak berpotensi termakan zakat tiap tahunnya apabila telah mencapai nișāb. ${ }^{11}$

Oleh sebab itu, seseorang yang memiliki harta konsumtif, kendatipun banyak jumlahnya, syara' tidak memandang pemiliknya sebagai orang kaya, karenanya ia pun tidak wajib berzakat. Hal ini disebabkan, harta semacam itu pada akhirnya akan menyedot anggaran pemeliharaan dan tidak memiliki nilai purna jual yang menguntungkan. Dalam hal ini dapat disimpulkan bahwa kepemilikan harta yang ideal

236

${ }^{10}$ Ibnu Kaṡir, Tafsir al-Qur'an al-Ażim, Jilid. I, (Cet. I; Beirut: Dār al-Kutub al-Ilmiyah, 1994), h.

${ }^{11}$ Andi Sarjan, Fikih Zakat, h. 15

Jurnal Ilmiah Al Tsarwah

Program Magister Program Studi Ekonomi Syariah

Institut Agama Islam Negeri (IAIN) Bone 
bagi seseorang adalah memiliki harta produktif lebih banyak dari harta konsumtif. Jika harta konsumtif saja yang dimiliki, dipastikan pemiliknya berada pada kategori orang yang rentan dengan kemiskinan dan pada gilirannya kurang sejahtera. ${ }^{12}$ Mengenai jumlah harta produktif yang menjadikan seseorang dipandang kaya dari sisi syara', akan dijelaskan dalam indikator kriterium kaya yang selanjutnya.

3) Mencapai nișāb

Ketentuan harta yang terkena kewajiban zakat harus mencapai nișāb, dipahami bahwa nișāb zakat sebagai tolok ukur (kriterium) kaya bagi pemilik harta. Nișāb adalah jumlah minimal yang telah ditetapkan sendiri oleh syara'. Wahbah al-Zuhailiy menjelaskan nișāb bagi jenis harta tertentu adalah indikator kaya bagi pemiliknya sehingga ia diwajibkan berzakat. Menurut Wahbah al-Zuhailiy, secara garis besarnya, nișāb yang dimaksud adalah 20 mišqāl untuk kekayaan emas, 200 dirham untuk kekayaan perak, lima wasaq (653 Kg.) untuk hasil-hasil pertanian, 40 ekor bagi ternak kambing, lima ekor bagi ternak unta, 30 ekor untuk ternak sapi. ${ }^{13}$ Korelasi rasionalisasi nișāb dengan kriterium kaya menurut ketetapan syara' bukan dalam pengertian kaya raya, melainkan kaya dalam arti standar. ${ }^{14}$

Yusuf Qarḍawiy menjelaskan, adanya Nabi saw. menetapkan nișāb hasil pertanian sebanyak lima wasaq (653 Kg.) karena jumlah itu sudah dapat memenuhi kebutuhan makan sejumlah keluarga sepanjang tahun, yang terdiri atas suami, istri, anak-anaknya, dan pembantunya. Anggaran makan seseorang adalah satu mud, sehingga nișāb sebanyak itu mencukupi kebutuhan makan mereka dalam setahun. Lebih lanjut Yusuf Qarḍawiy menjelaskan, ditetapkannya nișāb perak sebanyak 200 dirham karena jumlah sebanyak itu dapat memenuhi anggaran belanja rumah tangga sepanjang tahun dalam keadaan harga barang kebutuhan normal, inilah jumlah kebutuhan yang umum dijumpai bagi banyak negeri. ${ }^{15}$

Kriterium kaya untuk seorang muslim adalah hal yang sangat urgen, yang terkait dengan kewajiban syara' dengan hartanya. Urgensi kriterium kaya terutama berkaitan dengan kewajiban zakat. Batas-batas nișāb yang menunjukkan hal ini dapat ditampilkan dalam hadis berikut:

\footnotetext{
${ }^{12}$ Andi Sarjan, Fikih Zakat, h. 16

${ }^{13}$ Wahbah al-Zuhailiy, Al-Figh al-Islāmi wa 'Adillatuhu. Terj. Agus Efendi dan Bahruddin Fananny, Zakat: Kajian Berbagai Mazhab. (Bandung: Remaja Rosdakarya Offset, 1997), h. 102

${ }^{14}$ Andi Sarjan, Fikih Zakat, h. 18

${ }^{15}$ Yusuf Qarḍawiy, Fiqh al-Zakāh, Terj. Salman Harun dkk, h. 149

Jurnal Ilmiah Al Tsarwah

Program Magister Program Studi Ekonomi Syariah

Institut Agama Islam Negeri (IAIN) Bone
} 


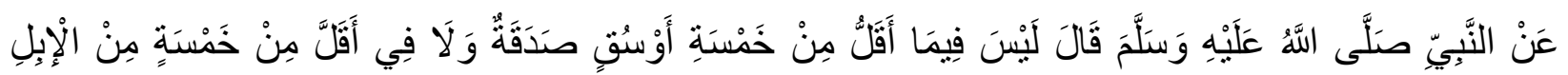

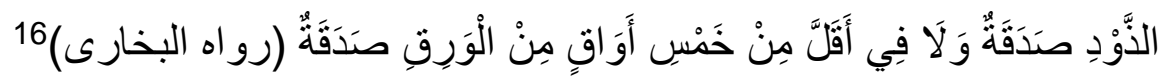
Artinya: Nabi saw. bersabda: "Tidak ada zakat pada hasil tanaman kurang dari lima wasaq, tidak ada zakat unta yang kurang dari lima ekor dan tidak ada zakat pada harta (uang) kurang dari lima waaq".(H.R. Bukhāri).

Dengan ketetapan nișāb sejumlah sumber zakat yang tersebut dalam hadis tersebut dengan uslub negasi melahirkan pemahaman bahwa orang yang memiliki harta tersebut kurang dari nișāb yang telah ditetapkan oleh Rasulullah saw. adalah orang- orang miskin yang tidak sejahtera hidupnya, sehingga tidak ada kewajiban zakat padanya. Sebagaimana dikemukakan, syara' sangat berhati-hati dalam menetapkan seseorang tergolong kaya, sejahtera, atau bahkan miskin. Ternyata nișāb zakat mengandung interpretasi tentang tingkat kemapanan ekonomi seorang muslim, karena nișāb itu sendiri adalah jumlah tertentu sebagai kelebihan dari seluruh pengeluaran belanja rumah tangga. Dengan pengertian ini, seorang muslim sudah dinyatakan telah berada pada tingkat kemapanan ekonomi, sehingga ia memperoleh kesejahteraan dalam hidupnya. ${ }^{17}$

Rasulullah saw. dalam hadisnya telah menetapkan nișāb sejumlah kekayaan tertentu pada masanya dengan nomina yang berbeda. Ternyata di balik perbedaan itu, fuqaha terutama kalangan mazhab Hanafi telah berkesimpulan bahwa kekuatan daya beli orang-orang kaya dari berbagai kalangan itu, seperti petani, peternak, pedagang, pemilik kekayaan emas dan perak, adalah sama. Mereka berpendapat bahwa semua orang kaya berada pada kriterium standar, yaitu pemilikan kekayaan senilai 200 dirham atau 20 dinar. ${ }^{18} \mathrm{Hal}$ ini dikenal dengan teori kesatuan nișāb (teori zakat konversi).

Fuqaha menjelaskan, uang dinar (uang emas) dapat dikurskan dengan uang dirham (uang perak), begitu juga sebaliknya. Berdasarkan penjelasan fuqaha, 20 dinar senilai dengan 200 dirham. Perbandingan nilai ini berdasar pada kadar zakat emas dan perak yang telah ditetapkan oleh Nabi saw. dengan ketetapannya bahwa tiap 20 dinar dibayarkan zakatnya 0,5 dinar, dan tiap 200 dirham dibayarkan zakatnya lima dirham. Kadar zakat emas dan perak adalah 2,5\%. Dengan demikian jika perbandingan kadar

\footnotetext{
${ }^{16}$ Muhammad bin Isma'il al-Bukhāri, Șahih Bukhāri, Juz. III. (Cet.III; Beirut: Dār al-Kutub alIImiyah, 2005), h. 366

${ }^{17}$ Andi Sarjan, Fikih Zakat, h. 19

${ }^{18}$ Andi Sarjan, Fikih Zakat, h. 20

Jurnal Ilmiah Al Tsarwah

Program Magister Program Studi Ekonomi Syariah

Institut Agama Islam Negeri (IAIN) Bone
} 
zakat emas dan perak itu dibulatkan, sehingga kurs dinar dengan dirham adalah 1:10. Artinya 1 dinar dapat ditukar dengan 10 dirham, begitu juga sebaliknya. ${ }^{19}$

Hal ini memberikan pemahaman tentang kesetaraan bagi para muzakki. Bahwa bagi petani yang memiliki hasil panen sebanyak lima wasaq, itu artinya senilai dengan 200 dirham, bagi pemilik ternak, 5 ekor unta senilai 200 dirham, 40 ekor kambing senilai 200 dirham, 10 ekor sapi senilai 200 dirham..$^{20}$ Ketentuan zakat māl secara rinci telah ditetapkan oleh Allah swt. dan Nabi saw. pada tahun kedua Hijriyah. Di antara ketetapan itu adalah nișāb sejumlah kekayaan yang menjadi sumber zakat di kala itu. Dengan demikian, nișāb adalah sebuah ketetapan syara' dan bukan hasil ijtihad fuqaha. Konsekuensinya adalah, umat Islam harus mematuhi apa adanya dan sebagaimana mestinya, dengan tidak menambah dan tidak mengurangi.

Kendatipun demikian, ada hal yang perlu dicermati yaitu pengaruh moneter terhadap nișāb zakat yang menjadi kriterium kaya tersebut. Bagaimanapun, kekayaan itu harus dinilai dengan uang, sehingga pemilik kekayaan tersebut dapat diketahui daya belinya. Nișāb zakat yang telah ditetapkan oleh Nabi saw. 14 abad lebih yang lalu sudah semestinya dianalisis dari segi moneter, agar yang berzakat itu benar-benar orang kaya. ${ }^{21}$ Berkenaan dengan hal tersebut sebelumnya. TM. Hasbi Ash-Shiddieqy menyatakan, mengenai nișāb ini perlu dilakukan peninjauan kembali agar orang-orang yang dikenakan pungutan zakat benar-benar memenuhi syarat sebagai orang kaya. Oleh karena nișāb ini adalah ketetapan syara' sendiri, bukan hasil ijtihad, ia tidak dapat berubah karena perubahan zaman dan perkembangan keperluan hidup. Hanya perlu ditekankan bahwa penentuan nișāb haruslah dengan emas, bukan dengan uang kertas. Uang kertas dinilai dengan emas sebesar 20 miṡqāl. ${ }^{22}$

Pemikiran TM. Hasbi Ash-Shiddieqy tersebut sejalan dengan ketentuan bagi muzakki bahwa ia benar-benar kaya. Orientasi pemikiran ini sangat beralasan seiring dengan berlalunya waktu penetapan nișāb oleh Nabi saw. yang cukup lama. Sehingga perubahan sistem keuangan Islam sangat mungkin terjadi. Ternyata, Islam di masa lalu yang menganut uang logam dengan sistem bimetalism emas dan perak, saat ini telah ditinggalkan. ${ }^{23}$ Nișāb sebagai ketetapan syara' harus berlaku sepanjang masa, namun

${ }^{19}$ Andi Sarjan, Fikih Zakat, h. 20

${ }^{20} \mathrm{Al}-\mathrm{Sarkhasi}$, Al-Mabsuț, Juz.III, (Beirut: Dār al-Fikr, 1989), h.3

${ }^{21}$ Andi Sarjan, Fikih Zakat, h. 20

${ }^{22}$ TM. Hasbi Ash-Shiddieqy, Beberapa Permasalahan Zakat, (Cet.l; Jakarta: Tintamas, 1976), h.

31

${ }^{23}$ Andi Sarjan, Fikih Zakat, h. 22

Jurnal Ilmiah Al Tsarwah

Program Magister Program Studi Ekonomi Syariah

Institut Agama Islam Negeri (IAIN) Bone 
sangat berpotensi dengan inflasi yang berakibat pada menurunnya daya beli muzakki. Akibat yang dapat muncul adalah terjadi kamuflase kriterium kaya akibat dari pemahaman simbol bilangan nișāb secara tekstual sejak ditetapkannya oleh Nabi saw. hingga sekarang. TM. Hasbi Ash-Shiddieqy dengan konsep kesatuan nișāb dengan emas, menegaskan bahwa tidak ada jalan lain kecuali semua nișāb harta kekayaan harus diukur dengan emas sebanyak 20 miśqāl/dinar. ${ }^{24}$

Untuk memperjelas kesatuan nișāb dengan emas sebanyak 20 mišqāl dengan taksiran berat $85 \mathrm{gr}$, ada baiknya memperhatikan tabel di bawah ini:

Tabel 02. Kesatuan nișāb dengan emas ${ }^{25}$

\begin{tabular}{|l|l|l|l|l|l|}
\hline No & $\begin{array}{c}\text { Jenis kekayaan } \\
\text { sumber zakat }\end{array}$ & \multicolumn{1}{|c|}{ Nișāb } & $\begin{array}{c}\text { Nilai Nișāb } \\
\text { berdasarkan harga } \\
\text { unit }\end{array}$ & $\begin{array}{c}\text { Daya } \\
\text { beli } \\
\text { emas }\end{array}$ & \multicolumn{1}{|c|}{ Ket. } \\
\hline 1 & Emas & $85 \mathrm{gr}$ & $\begin{array}{l}\text { Rp.592.000/g } \\
\text { Rp.50.320.000 }\end{array}$ & $85 \mathrm{gr}$ & $\begin{array}{l}\text { Nișāb standar } \\
85 \text { gr. }\end{array}$ \\
\hline 2 & Unta & 5 ekor & $\begin{array}{l}\text { Rp.14.000.000/ekor } \\
\text { Rp.70.000.000 }\end{array}$ & $118 \mathrm{gr}$ & $\begin{array}{l}\text { Terkoreksi } \\
\text { Positif } 33 \mathrm{gr}\end{array}$ \\
\hline 3 & Sapi & 10 ekor & $\begin{array}{l}\text { Rp.9000.000/ekor } \\
\text { Rp.90.000.000 }\end{array}$ & $152 \mathrm{gr}$ & $\begin{array}{l}\text { Terkoreksi } \\
\text { Positif } 67 \mathrm{gr}\end{array}$ \\
\hline 4 & Kambing & 40 ekor & $\begin{array}{l}\text { Rp.1.300.000/ekor } \\
\text { Rp.52.000.000 }\end{array}$ & $87 \mathrm{gr}$ & Relevan \\
\hline 5 & $\begin{array}{l}\text { Hasil pertanian } \\
\text { (beras) }\end{array}$ & $653 \mathrm{Kg}$ & $\begin{array}{l}\text { Rp. } 8.500 / \mathrm{Kg} \\
\mathrm{Rp} .5 .500 .500\end{array}$ & $\begin{array}{l}9,291 \\
\mathrm{gr}\end{array}$ & $\begin{array}{l}\text { Terkoreksi } \\
\text { Negatif } 75,70 \mathrm{gr}\end{array}$ \\
\hline 6 & Perak & $200 / 600 \mathrm{gr}$ & $\begin{array}{l}\text { Rp.10.000 } \\
\text { Rp.6000.000 }\end{array}$ & $\begin{array}{l}10,135 \\
\mathrm{gr}\end{array}$ & $\begin{array}{l}\text { Terkoreksi } \\
\text { Negatif } 74,86 \mathrm{gr}\end{array}$ \\
\hline
\end{tabular}

Berdasarkan pada tabel yang dikemukakan sebelumnya, terlihat beberapa nișāb seperti hasil pertanian dan perak terkoreksi negatif daya belinya, sesuai dengan nișāb yang telah ditetapkan oleh Nabi saw. apabila segala nișāb harta kekayaan ditetapkan dengan emas saat ini. Dengan demikian, sangat wajar jika kehati-hatian dalam menetapkan seseorang sebagai muzakki harus ditempuh untuk menghindari kesemuan status kaya seseorang. Misalnya, yang terkoreksi tajam daya beli muzakki adalah golongan petani dan pemilik kekayaan perak. Kendati demikian, nișāb hewan ternak justru terkoreksi positif. Hal ini disebabkan tingginya harga-harga daging di Indonesia.

${ }^{24}$ TM. Hasbi al-Shiddieqy, Pedoman Zakat, h. 111

${ }^{25}$ Daftar harga dari berbagai sumber website per april 2017, lihat m.liputan6.com, www.daftarhargaku.info/harga-emas-antam, www.hargapalingbaru.com, makassar.tribunnews.com, diakses 3 mei 2017

Jurnal Ilmiah Al Tsarwah

Program Magister Program Studi Ekonomi Syariah

Institut Agama Islam Negeri (IAIN) Bone 
Berdasarkan akses informasi tentang terminologi kaya diperoleh kesimpulan bahwa satu-satunya pranata yang menunjukan kriterium kaya dalam syariat Islam adalah zakat. Selain hal tersebut, nișāb zakat adalah indikator yang terukur untuk menentukan seseorang menjadi kaya, dan untuk zaman sekarang, penentuan nișāb harus dengan emas sebanyak 20 mišqāl/dinar. Sehingga muzakki benar-benar memenuhi syarat disebut sebagai orang kaya menurut syariat Islam. ${ }^{26}$

1. Kriterium Kaya Sebagai Pertimbangan Syar'i dalam PERDA-PERDA Zakat Profesi di Sulawesi Selatan.

Legislasi hukum Islam di Indonesia mengalami proses yang cukup panjang. Begitupun dengan legislasi hukum zakat, sampai akhirnya ditetapkan dalam bentuk perundang-undangan, yakni Undang-undang Republik Indonesia Nomor 38 tahun 1999 tentang pengelolaan zakat, kemudian diganti dengan Undang-undang Republik Indonesia Nomor 23 tahun 2011. Lahirnya kedua undang-undang tersebut, menjadi dasar bagi Pemerintah Daerah di seluruh Indonesia untuk menetapkan peraturan yang sama pada level daerah, berupa Peraturan Daerah tentang pengelolaan zakat.

Di Provinsi Sulawesi Selatan, terdapat sembilan daerah tingkat kabupaten/ kota yang menetapkan PERDA tentang pengelolaan zakat. Pada umumnya Peraturan Daerah tentang pengelolaan zakat di Sulawesi Selatan tidak berbeda dengan Undangundang pengelolaan zakat yang menitikberatkan pada pengelolaan zakat oleh Badan Amil Zakat termasuk pendistribusiannya, serta pengaturan beberapa sumber-sumber zakat yang tergolong baru, seperti halnya penetapan zakat profesi.

Namun, terdapat perbedaan dalam pengaturan zakat profesi pada kesembilan PERDA yang ada di Sulawesi Selatan. Perbedaan pengaturan zakat profesi tersebut disebabkan perbedaan qiyas hukum zakat profesi kepada sumber-sumber zakat lainnya. Ada yang menqiyaskan zakat profesi kepada zakat pertanian dan ada pula yang menqiyaskannya kepada zakat emas dan perak atau zakat perdagangan. Perbedaan qiyas yang digunakan tentu berdampak pada perbedaan hasil ijtihad.

Dari hasil analisis penulis terhadap pasal-pasal yang terkait dengan zakat profesi yang diatur di dalam PERDA-PERDA tentang pengelolaan zakat di Sulawesi Selatan, pengaturan zakat profesi dapat digolongkan ke dalam tiga kategori, yaitu; Pertama, PERDA yang mengatur zakat profesi diqiyaskan ke zakat pertanian, yakni PERDA Kabupaten Bone. Hal ini diatur secara jelas dalam BAB VII tentang kadar

${ }^{26}$ Andi Sarjan, Fikih Zakat, h. 27

Jurnal Ilmiah Al Tsarwah

Program Magister Program Studi Ekonomi Syariah

Institut Agama Islam Negeri (IAIN) Bone 
zakat, Pasal 18. Kedua, PERDA yang mengatur zakat profesi diqiyaskan ke zakat emas, yakni PERDA Kabupaten Maros, diatur secara jelas dalam BAB VIII tentang besarnya kadar zakat, Pasal 17. Selanjutnya PERDA Kabupaten Bulukumba dan PERDA Kota Palopo, tidak secara langsung qiyasnya ke zakat emas, namun adanya indikasi berupa penetapan kadar zakat $2,5 \%$ dan ditetapkan haul, hal ini penulis simpulkan bahwa PERDA ini termasuk dalam kategori kedua. Hal ini terdapat dalam BAB VIII Pasal 22, dan BAB VII Pasal 23.

Ketiga, PERDA yang tidak secara langsung menetapkan qiyas zakat profesi, melainkan berdasarkan aturan BAZDA dan atau berdasarkan fikih zakat, yakni PERDAPERDA Kota Makassar, Kota Pare-pare, Kabupaten Luwu Timur, Kabupaten Wajo, dan Kabupaten Kepulauan Selayar. Menariknya, PERDA-PERDA dalam kategori ketiga ini seakan salinan antara satu dengan yang lainnya. Oleh karena, tiap PERDA mengatur hal ini pada Pasal 8, meski ada perbedaan dalam penomoran bab.

Pengelompokan PERDA ke dalam tiga kategori, bertujuan untuk melihat bahwa dalam pengaturan zakat profesi dalam PERDA-PERDA zakat di Sulawesi Selatan, terdapat beberapa yang belum memenuhi kriterium kaya sebagaimana yang telah dijelaskan pada pembahasan kriterium kaya dalam zakat harta, karena zakat profesi merupakan zakat harta kekayaan.

Seperti halnya PERDA Kabupaten Bone yang secara jelas mengatur zakat profesi, mewajibkan para profesional/ pegawai/ karyawan yang penghasilannya setara dengan harga $653 \mathrm{Kg}$ beras. Besaran nișāb zakat profesi diqiyaskan kepada zakat pertanian. Namun, yang wajib dibayar adalah $2,50 \%$, bukan $10 \%$ atau $5 \%$ sebagaimana zakat pertanian yang semestinya. Terlihat penetapan hukum zakat profesi telah terjadi inkonsistensi di dalamnya, yaitu qiyasnya ke pertanian, namun kadar zakatnya adalah logam mulia atau perdagangan.

Dari segi metodologi istinbat tentu inkonsistensi tersebut tidak dibenarkan. Qiyas harus memiliki 'illat yang valid, sehingga melahirkan hukum yang pasti pula. Akibat buruk yang muncul adalah melanggar beberapa ketentuan dan filosofi hukum zakat itu sendiri. Bahwasannya zakat hanya diperintahkan (diwajibkan) bagi yang kaya, dengan penghasilan karyawan atau pegawai senilai Rp. 5.500 .500 yakni harga dari 653 $\mathrm{Kg}$ beras, dapat dipastikan tidak memenuhi kriteria kaya seiring dengan laju inflasi dari waktu ke waktu. Begitu juga, dengan memotong gaji mereka dalam bentuk bruto

\footnotetext{
Jurnal Ilmiah Al Tsarwah
}

Program Magister Program Studi Ekonomi Syariah

Institut Agama Islam Negeri (IAIN) Bone 
(kotor), itu artinya menyalahi filosofi nișāb sebagai syarat wajib zakat, yaitu kelebihan dari pemenuhan kebutuhan pokok. ${ }^{27}$

Selain hal tersebut, pemahaman analogi zakat profesi kepada zakat hasil bumi dan dilakukan tiap kali menerima gaji/upah, itu artinya zakat dipungut berkali-kali menyalahi filosofi haul. Dengan haul, syara' bermaksud menghindarkan muzakki terkena berkali-kali zakat sehingga terbebani. Petani memang dapat panen dua sampai tiga kali dalam setahun, tidak 12 kali sebagaimana yang terjadi pada zakat profesi saat ini. $^{28}$

Menurut Husein al-Syahatah sebagaimana dikutip dalam Andi Sarjan, yang paling baik dianut adalah pendapat sebagian fuqaha yang menqiyaskan zakat profesi itu kepada zakat logam mulia (emas dan perak). ${ }^{29}$ Dengan standar nișāb penghasilan senilai 85 gram emas murni. Adapun kadar zakatnya sebesar $2.50 \%$ dan haul selama satu tahun.

Oleh karena itu, sebaiknya kriterium kaya menjadi salah satu pertimbangan syar'i dalam menetapkan zakat profesi yang diatur di dalam PERDA zakat di Sulawesi Selatan. Kriterium kaya yang dimaksud adalah kesatuan niṣāb emas 20 mišqāl dan dikeluarkan dari penghasilan bersih (netto), sehingga zakat yang dikeluarkan benar merupakan kelebihan dari kebutuhan pokok.

\section{KESIMPULAN DAN SARAN}

\section{Kesimpulan}

Setelah diuraikan sebelumnya tentang kriterium kaya dalam zakat profesi, maka penulis menarik beberapa kesimpulan sebagai berikut:

1. Penetapan kriterium kaya dalam zakat harta (māl) pada dasarnya mewajibkan zakat hanya untuk orang-orang kaya. Oleh karena itu, kriterium kaya dapat diartikan sebagai tolok ukur yang digunakan syara' dalam menetapkan seseorang disebut kaya. Syarat wajib zakat, seperti lebih dari kebutuhan dan bebas dari hutang, harta yang produktif, serta harta mencapai nișāb, merupakan indikator dalam mengukur tingkat kekayaan seorang

${ }^{27}$ Andi Sarjan, Fikih Zakat, h. 93

${ }^{28}$ Andi Sarjan, Fikih Zakat, h. 93

${ }^{29}$ Andi Sarjan, Fikih Zakat, h. 94

Jurnal Ilmiah Al Tsarwah

Program Magister Program Studi Ekonomi Syariah

Institut Agama Islam Negeri (IAIN) Bone 
muslim, bukan dalam pengertian kaya raya, melainkan kaya dalam arti standar.

2. Seharusnya kriterium kaya menjadi salah satu pertimbangan syar'i dalam menetapkan kewajiban zakat profesi dalam PERDA zakat di Sulawesi Selatan. Kriterium kaya yang dimaksud adalah kesatuan nișāb emas 20 mišqāl dan dikeluarkan dari penghasilan bersih (netto).

\section{Saran}

Adapun implikasi penelitian yang diharapkan, Pemerintah dalam menetapkan Peraturan Daerah yang sumber utama dan bahan bakunya merupakan hukum Islam, sebaiknya memperhatikan berbagai pertimbangan. Utamanya pertimbangan dari berbagai pendapat ulama, seperti Majelis Ulama Indonesia (MUI) yang memfatwakan zakat profesi diqiyaskan kepada zakat emas dengan standar nișāb 85 gram emas. Begitu juga, sebaiknya kriterium kaya menjadi salah satu pertimbangan syar'i dalam menetapkan kewajiban zakat profesi yang diatur di dalam PERDA zakat di Sulawesi Selatan.

\section{DAFTAR PUSTAKA}

Al-Qur'an al-Karim.

Abu Dāwud, Sunan Abi Dāwud, , Jilid. I, Cet. III; Beirut: Dār al-Kutub al-IImiyah, 2011. Abu Ubaid, Al-Amwāl. Beirut: Dār al-Fikr. 1988.

Andi Sarjan. Fikih Zakat Dalam Kajian Normatif, Kontekstual, dan Kontemporer, (Cet. I ; Yogyakarta: PRUDENT MEDIA, 2013

------. Keuangan Islam Publik, Teori, Praktek, dan Pengembangannya di Masa Kini, Watampone: Lukman al-Hakim Press, 2015

Ash-Shiddieqy, TM. Hasbi. Beberapa Permasalahan Zakat. Cet. I; Jakarta: Tintamas, 1976.

------. Pedoman Zakat. Cet. V; Jakarta: Bulan Bintang, 1984

Al-Bukhāri, Muhammad bin Isma'il. Șahih Bukhāri. Juz. III. Cet.III; Beirut: Dār al-Kutub al-Ilmiyah, 2005.

Departemen Agama RI, al-Qur'an dan Terjemahnya, Semarang: CV.Toha Putra, 1989 Hafidhuddin, Didin. Zakat dalam Perekonomian Modern, Cet. I; Jakarta: Gema Insani Press, 2002

Jurnal Ilmiah Al Tsarwah

Program Magister Program Studi Ekonomi Syariah

Institut Agama Islam Negeri (IAIN) Bone 
Ibnu Kaṡir. Tafsir al-Qur'an al-Ażim. Jilid. I. Cet. I; Beirut: Dār al-Kutub al-IImiyah, 1994. Ibnu Rusyd. Bidāyat al-Mujtahid. Beirut: Dār al-Fikr, 1995.

Kurnia, Hikmat \& Ade Hidayat. Panduan Pintar Zakat. Cet.l; Jakarta: Qultum Media, 2008.

Munawwir, Achmad Warson. Kamus al-Munawwir, Arab-Indonesia, Ed. I, Surabaya: Pustaka Progresif, 1997

Al-Qardawiy, Yusuf. Al-Ibadah fi al-Islam. Beirut: Muasasah Risalah, 1993.

-----. Fiqh al-Zakat. Terj. Salman Harun dkk, Hukum Zakat. Cet. II; Bogor: Pustaka litera AntarNusa, 2004.

Al-Qurțubi. Tafsir al-Jāmi' li Ahkam al-Qur’an. Juz. IX . Beirut: Dār al-kutub al-Ilmiyah, 1993.

Qadir, Abdurrahman. Zakat dalam dimensi mahdah dan sosial. Jakarta: Raja Grafindo Persada, 1998.

Al-Sarkhasi, Al-Mabsuth. Juz.III. Beirut: Dār al-Fikr, 1989.

Sabiq, Sayyid. Fiqh al-Sunnah, Terj. Mahyuddin Syaf, Fikih sunnah, Cet.Il; Bandung: Pustaka al-Azhar, 1990.

Shobirin, Teknik Pengelolaan Zakat Profesi, Jurnal ZISWAF, Vol. 2, No. 2, Desember 2015.

Zuhdi. Masjfuk. Masail Fiqhiyah: Kapita Selekta Hukum Islam. Jakarta: CV Haji Masagung, 1989.

Al-Zuhailiy, Wahbah. Al-Fiqh al-Islāmi wa 'Adillatuhu. Juz II. Damaskus: Dar al-Fikr, 1989.

------. Al-Fiqh al-Islāmi wa 'Adillatuhu. Terj. Agus Efendi dan Bahruddin Fananny, Zakat: Kajian Berbagai Mazhab. Bandung: Remaja Rosdakarya Offset, 1997.

Jurnal Ilmiah Al Tsarwah

Program Magister Program Studi Ekonomi Syariah

Institut Agama Islam Negeri (IAIN) Bone 
Jurnal Ilmiah Al Tsarwah

Program Magister Program Studi Ekonomi Syariah

Institut Agama Islam Negeri (IAIN) Bone 